\title{
Factors Affecting Attitudes Towards Entrepreneurship: A Case Study of CBA Students at Kuwait University
}

\author{
Mohammad Qasem Ahmad (Al-Qarioti) $)^{1, *}$ \\ ${ }^{1}$ Dept. of Public Administration, College of Business, Kuwait University, Kuwait \\ *Corresponding author: Dept. of Public Administration, College of Business, Kuwait \\ University, Kuwait. Tel: 965-97-923-656. E-mail: qarioti@ cba.edu.kw
}

Received: July 16, 2019 Accepted: August 24, 2019 Published: September 8, 2019

doi: 10.5296/jcgr.v3i1.15412 URL: https://doi.org/10.5296/jcgr.v3i1.15412

\begin{abstract}
This study investigated attitudes towards entrepreneurship of students at the College of Business Administration (CBA) at Kuwait University (KU), attitudes relationships to individual characteristics and contextual and demographic factors. A conceptual framework of four major constructs was designed. It included individual characteristics, contextual factors, demographic factors, and entrepreneurial attitudes. Data were collected using a self-administrated questionnaire. Questionnaires were distributed to a stratified random sample of (600) senior and junior students. The response rate was $98 \%$. Study findings showed positive individual characteristics and contextual conditions towards entrepreneurship. Moreover, the results showed strong positive correlations between students' attitudes, individual characteristics, and contextual conditions. The study results showed no significant correlations between students' attitudes, gender, and nationality, however, there was a correlation between attitudes and major. The study reached conclusions, noted some practical implications, and makes recommendations.
\end{abstract}

Keywords: Entrepreneurship, Attitudes, Individual characteristics, Contextual conditions, Kuwait University, CBA

**This Study was funded by the Research Administration at Kuwait University (Project No. IU01/17). 


\section{Study Problem, Objectives, Importance, Questions, Hypotheses, and Methodology}

\subsection{Introduction}

This study discusses entrepreneurship, which is an increasingly researched field, which has attracted considerable academic effort. This is an important topic, which occupies an important position in countries' economies. Much effort has focused on entrepreneurship education as a way to develop and gain momentum in this field, and on encouraging entrepreneurs to start their own businesses view entrepreneurship as a major strategy that can contribute to solving economic and social problems such as unemployment and poverty. Entrepreneurship education has become an essential economic, social phenomenon and an academic field (Fayolle and Gailly, 2008: 569; Niyonkuru, 2005: 6; GEM, 2006). With the rapid evolution of complex technologies and globalisation, the creation and development of innovative private initiatives has become a national priority in many countries. Kuwait is one of those countries, which views entrepreneurship an opportunity to produce positive changes in economic and social spheres by encouraging citizens to start their own projects and be self-employed. The reason behind this encouragement is due to the fact that most governments including Kuwait are not able to provide sufficient job opportunities in the public sector any more (AL Zu'bi, 2018).

\subsection{Problem Statement}

The study investigated the attitudes of students at the College of Business Administration (CBA) at Kuwait University (KU) towards entrepreneurship, relationships to individual characteristics, contextual factors, and demographic factors. The assumption is that entrepreneurship is a function of individual characteristics and contextual conditions. The individual characteristics, which were studied, included optimism, innovativeness, risk-taking tolerance and need for achievement. Contextual conditions included personal experiential activities, entrepreneurship education, immediate family entrepreneurial experiences, and the students' socio-economic and cultural conditions. Demographic factors included major, gender and nationality.

\subsection{Research Objectives}

The study main objective was to investigate the positivity of individual characteristics and contextual conditions towards entrepreneurship. Besides this, the study aims to see how individual characteristics, contextual conditions and demographic factors relate to attitudes.

Specifically, the study objectives were as follows:

1. Investigate whether CBA students' entrepreneurship attitudes differ according to individual and demographic characteristics and contextual conditions.

2. Provide recommendations how to motivate students towards entrepreneurship.

\subsection{Research Importance}

Entrepreneurship in Kuwait has attracted great attention due to increasing recognition of its essential role in enhancing economic development. Many measures have been taken to encourage private initiative and to provide facilities for entrepreneurs. This demonstrates a 


\section{Macrothink}

political will at the top level. Encouragement od entrepreneurship in Kuwait is a major strategy to move the burden of employment from the public to the private sector (AL ASH-Shakya, 2018). The study is significant from a scientific perspective because it can contribute to literature on entrepreneurship in Kuwait. From a practical perspective, the study sheds light on how positive individual characteristics and contextual factors can shape students' attitudes towards entrepreneurship. The researcher hopes to reach some recommendations on how to motivate CBA students' entrepreneurial attitudes.

\subsection{Research Limitations}

One limitation of this study is its focus on CBA students at Kuwait University, which makes it difficult to make broad generalisations about entrepreneurship attitudes of business students in Kuwait in general. A second limitation was limited time, effort and budget allocated for the research after budget cuts for research by the Research Administration at KU.

\subsection{Conceptual Framework}

Independent Variables

Dependent Variable

Individual characteristics

\& contextual factors

* Individual characteristics

- Optimism

- Innovativeness

- Risk taking

- Need for achievement

* Contextual factors

- personal experiential activities

$-$

- Entrepreneurship education \& incentives

- Immediate family exposure to entrepreneurship

- Socio- Economic factors

- Cultural factors

* Demographic factors

- Major

- Gender

- Nationality

\section{Entrepreneurial} Attitudes

(Intentions to become entrepreneurs)

Figure 1.1. Research Conceptual Framework 


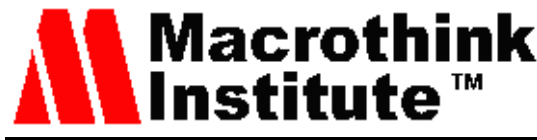

Journal of Corporate Governance Research ISSN 1948-4658 2019, Vol. 3, No. 1

The conceptual framework of this study as shown in figure 1 stems from academic and practical experience. It describes independent and dependent variables. Independent variables include individual and demographic characteristics, and contextual conditions. Individual characteristics include optimism, innovativeness, risk taking and need for achievement. Contextual factors included personal experiential activities, entrepreneurship education, immediate family exposure to entrepreneurship, and socioeconomic and cultural conditions. Demographic factors include the students' major, gender and nationality. The dependent variable was students' entrepreneurial attitudes.

The following theoretical framework defines the key concepts.

\subsubsection{Entrepreneurship}

Entrepreneurship focuses on how, by whom, and with what effects, and how to discover, evaluate, and exploit opportunities to create jobs, goods and services (Shane \& Venkataraman, 2000, p. 218). From this perspective, there are four important elements of entrepreneurship: opportunities, individual characteristics of entrepreneurs, entrepreneurial orientation and contextual factors (Carlsson et al., 2013, p. 925). This view emphasized that entrepreneurship introduces opportunities, as without an opportunity there can be no entrepreneurship (Short et al., 2010, p. 40, 55). Many researchers analyse how opportunities arise, and whether they are established or revealed by entrepreneurs (Alvarez \& Barney, 2007; Corner \& Ho, 2010, p. 636). Entrepreneurship as an opportunity-related process, which involves assessing and exploiting these opportunities. (Shane \& Venkataraman, 2000, p. 218; Short et al., 2010; Carlsson et al., 2013, p. 922).

The term 'entrepreneurship' is derived from the French word 'entreprendre', which means, "to take into one's own hands" (Roberts \& Woods, 2005, p. 46). One of the earliest scholars, Jean-Baptiste, described an entrepreneur as an individual who moves economic resources out of a lower productivity area into a higher productivity and greater yield area (Drucker, p. 19; Dees, 2007, p. 1). Cantillon viewed entrepreneurs as risk-takers who create and exchange goods and services (Saucier \& Thornton, 2010, p. 6; Cantillon, 2010). Schumpeter and other Austrian economists studied entrepreneurship during the $20^{\text {th }}$ century (Carlsson et al., 2013, p. 917). According to Schumpeter, entrepreneurs are innovators who perform the creative process of capitalism (Dees, 2007, p. 1). The focus of economic research in the 1950s and 1960s moved towards larger enterprises during the 1950s and 1960s. Behavioural scientists stepped in to study entrepreneurship further. This led to entrepreneurship research, which concentrated, on the behavioural and psychological aspects of individual characteristics and traits of entrepreneurs. Since the 1980s, economic changes increased motivation to create new and small enterprises, which increased popularity to investigate entrepreneurship as a field of study and increased its importance within the literature (Carlsson et al., 2013, p. 918-921). As mentioned by Drucker, an entrepreneur frequently searches for a change, responds to it, and exploits it as an opportunity (Drucker, 1985b, 25-31). Henceforth, Deeds, Schumpeter and Drucker define entrepreneurship as a mind-set and a type of behaviour that can be established everywhere (Dees, 2007, p. 2).

The research field of entrepreneurship grew to be one of the most relevant, dynamic and vital 
fields in the social sciences, economics and management domains (Wiklund et al., 2011, p. 1). However, there is no single recognised definition of entrepreneurship. Several definitions of entrepreneurship focus on the individual entrepreneur (Venkataraman, 1997, p. 120). Some researchers argue that entrepreneurship is a theory that is driven and mostly concerned with the context of small businesses. They therefore, they called for a move from a context-based view of entrepreneurship to a phenomenon-based view of entrepreneurship to a phenomenon-based view. (Wiklund et al., 2011, p. 1-5). Harvard Business School definition, of entrepreneurship is "the pursuit of opportunity beyond resources controlled" (Eisenmann, 2013). This definition emphasises that entrepreneurs perceive a window of opportunity, a sense of urgency and resource constraints. Due to these factors, entrepreneurs face considerable risk and pursue a new opportunity while lacking access to required resources. Further, Dyer et al., mentioned five skills of innovative entrepreneurs, which are different from typical executives. These skills involved experimenting, observing networking, questioning and associating (Dyer, et.al. 2009).

\subsubsection{Entrepreneur}

An entrepreneur refers to an individual who acts independently or through several organisations to realise and establish new opportunities, exploit and evaluate them by using innovation and by presenting an individual's main ideas within the market ambiguity. In particular, an entrepreneur is a person who organizes a new venture, manages it, and bears the associated risks affecting it. This definition is broad enough to include business owners, innovators and executives who need a capital to start a new project, introduce a new product or expand a promising line of business. Further, this view includes technology transfer, experts, technologists, consultants and advisors assisting in all aspects of venturing. An entrepreneur's principal objectives are profit and growth using strategic management practices are used to achieve them.

Moreover, entrepreneurship is not limited to a particular type of organisation, but it can include different sectors and new businesses (Drucker, 1985a, p. 67; Shane \& Venkataraman, 2000, p. 219). Entrepreneurs mobilise and use various kinds of resources, including social capital and networks, and human and financial resources (Audretsch, 2012, p. 761-762; Drucker, 1985a, p. 67; Shane \& Venkataraman, 2000, p. 219; (Audretsch, 2012, p. 761-762, Oviatt \& McDougall, 1994). There are various entrepreneurship types of economic and social, sustainable entrepreneurship. Economic entrepreneurship refers to business for profit activities, which benefit the society in the form of creating new and valuable goods, services and jobs, and transformative social impacts. (Mack \& Pützschel, 2014; Austin et al., 2006, p. 3, Abu-Saifan, 2012, p. 22; Carlsson et al., 2013, p. 913). Social entrepreneurship follows an innovative method that performs efficiently with social issues. It reduces the boundaries between the public and private sectors, and allows the creation of new arrangements such as hybrid enterprises (Bacq \& Janssen, 2011, p. 374-375; Dees, 2001, p. 1; Bornstein, 2004, p. 1; Austin et al., 2006, p. 2; Choi \& Majumdar, 2013, p. 36). Sustainable entrepreneurship refers to entrepreneurship activities, which aim to support social and ecological values maintaining a sustainable society and ecosystem. It meets the needs of the present generation, but not at the expense of the future generations (Thompson et al.,, 2011, p. 210, 212; WCED, 1987, p. 15). 


\subsubsection{Individual Characteristics of Entrepreneurs}

The entrepreneurial process includes different outcomes, moderators and antecedents. Furthermore, it is affected by individual characteristics of entrepreneurs and contextual conditions in the environment (Short et al., 2010; Gartner, 1985). The commitment of an individual to entrepreneurship is characterised by the communication between situational factors and individual characteristics that could stimulate the manifestations pertaining to the personality traits and the motivation to begin setting up a new business (Choi et al., 2015, 1543; Hattab, 2014; Gladwell, 2013). An important question regarding entrepreneurship is "What distinguishes entrepreneurs from other people" As mentioned above; entrepreneurs have frequently been seen as individuals who set up their own new business, taking risk and work under uncertainty (Drucker, 1985b, p. 19; Short et al., 2010, p. 58).

Entrepreneurship is an economic activity or a venture in which individuals or groups are engaged to act independently or within their organizations. They perceive, create, exploit and assess new opportunities by using innovation and by introducing new concepts to the market under uncertainty. Such activities and ventures are affected by individual characteristics and contextual factors. There is extensive research on the personal character traits of entrepreneurs in order to differentiate them from individuals who do become entrepreneurs (Gartner, 1985, p. 698; Ajzen, 2002; Krueger et al., 2000; and Kolvereid \& Isaksen, 2006; Carland et al., 1984, p. 355-357).

Several researchers have investigated individual character traits of entrepreneurs in order to differentiate them from non-potential entrepreneurs. The literature has shown that individual characteristics and contextual factors affect the entrepreneurial process. Most of these factors are not unique to entrepreneurs, but are rather common to many successful individuals, including managers (Gartner, 1985, p. 698; Boyd and Vozikis, 1994, p. 63; Drucker, 1985a, pp. 23, 67). Further, different situational factors of entrepreneurs, such as the need for personal development or individuality, can affect their decision or motivation to become entrepreneurs (Burns, 2011, p. 53-55). Those factors could affect the entrepreneurial process. (Gartner, 1985, p. 700-701, 704). Ajzen's theory of planned behaviour suggests that the immediate antecedent of behaviour is the attitude to perform a given behaviour. Additionally, Krueger et al., and Kolvereid \& Isaksen argue that attitudes represent the most effective single predictor related to the most planned entrepreneurial behaviour (Ajzen, 2002; Krueger et al., 2000; and Kolvereid \& Isaksen 2006). In Ajzen's TPB model, attitudes are identified by perceived behavioural control, attitude and subjective norms (Ajzen, 2002).

Qualities and individual characteristics play a vital role in entrepreneurship. The present research focuses on certain individual characteristics, which include optimism, innovativeness, risk-taking tolerance and the need for achievement, which we define below (Ajzen, 1991). Optimism refers to individual characteristics and qualities, which are connected to personality and occupy an important role. Additionally, it refers to the desire to be successful and perform efficiently to realise one's dreams (Seligman, 2006). It can be a result of motivation and optimism of personal success and social success as a benefactor for the reputation in which the creation allows to acquire (Shapero, et al., 1982). Innovativeness refers to the process of 
switching knowledge and ideas into new values within creative thinking. Optimism is the propensity and ability to think in a creative way and recognise the chances of creating ideas that are novel and practical, establishing new markets and representing new services and products (Chen, 2007; Gupta et al., 2004). Based on several studies, innovation is the "defining characteristic" or "specific instrument" of entrepreneurship. According to Drucker, innovation indicates, "the means by which entrepreneurs exploit change as an opportunity for a different business or a different service" (Burns, 2011, p. 86; Drucker, 1985b, p.17-27; Drucker, 1985b). Drucker mentions various resources for an innovative opportunity outside or within the industry or enterprise, such as changes in meanings, perceptions and demographics or current knowledge (Chen, 2007; Gupta et al., 2004; Drucker, 1985b: 31-32). Risk taking tolerance refers to an individual tendency to take risks in addition to being tolerant to the uncertainties involved in being engaged in new experiences. The risk-taking dimension includes all these factors that are related to how individuals of a culture deal with certain risks, and how they observe general risks. Individuals with a greater risk tolerance have stronger levels of entrepreneurial intention (Hmieleski and Corbett, 2006). Need for achievement refers to a personal trait to excel and to reach specific purposes for personal achievements. (Rauch and Frese, 2007). In a competitive business world, entrepreneurs tend to thrive on competitive spirit with standards of excellence to win and excel not only others but also themselves. The need for achievement is a way to distinguish creators from non-creators (Bacq \& Janssen, 2006; McClelland 1961, 1965, and 1969). A high need for achievement is a result of discovering new products, new techniques and new knowledge. In order to build an idea, it is important to have good networks and frequently see good actors (Boissin, 2009).

\subsubsection{Contextual Conditions}

Several researchers within social science domain have pointed to relationships between entrepreneurship, individual characteristics and contextual factors. From a system approach, contextual conditions are influential in affecting people's attitudes in all spheres. Contextual conditions include antecedent factors such as education, family, gender, social group, previous employment, culture, ethnicity, immigration, and religion (Burns, 2011, p. 34, 42-53, 53-55). In management research, the concept 'context' refers to environments, conditions, circumstances and situations that are external to a related phenomenon, but enable it (Welter, 2011, p. 167). Literature on strategic management acknowledges the role of those factors by developing models, which can analyse social and legal environments, political, and economic, technological and environmental economics that might impact on many organisations (PESTEL) (Johnson et al.,, 2011, p. 49-51; Yüksel, 2012, p. 53). Entrepreneurs do not operate in a vacuum. Formal and informal contextual factors influence each other in entrepreneurship (Gartner, 1985, p. 700-702; Gnyawali \& Fogel, 1994, p. 44; Salimath \& Cullen, 2010, p. 367-372; Tonoyan et al.,, 2017, p. 805).

\subsubsection{Kuwaiti Contextual Conditions}

Possessing the needed traits is insufficient to guarantee that a person will begin setting up a new business. Based on trait activation theory, national cultures could activate the expression of particular characteristics of a personality (Choi et al., 2015). Cross-cultural differences 
impact on the size of the entrepreneurial sector for the institutional factors. Directness and social contacts help entrepreneurs to explore and apply new ideas. Individual characteristics are important start businesses, and can assist inclined personalities to start businesses, and improve the efficiency of industrial organisations (Gladwell, 2013). In order to encourage an entrepreneurship through an individual career path, innovation should be encouraged within a supportive environment. According to this analysis, it is sensible to briefly mention the political, socio-economic and cultural conditions, which might affect entrepreneurship. Kuwait is a small country of 17,818 square Kilometres. It enjoys a strategic location in the Arabian Gulf. In 2016, it had a population of 4.2 million people of whom 1.3 million were Kuwaitis and 2.9 million were expatriates. Kuwait has a semi-democratic political system. It has a conservative culture, which sets economic norms where women bear the main responsibility for taking care of children, and face resistance to them following other careers, which may be deemed to be culturally unsuitable (Reimers et al., 2013). Regarding culture, Kuwaitis encourages the expression of some personality traits that are beneficial to high-growth entrepreneurship. Some of these traits comprise conscientiousness and openness, which form an important threshold for entrepreneurial aptitude (Bills, 2015). Kuwait culture has Arabic and Islamic foundations with significant western influence, as it is the intersection of three continents, which opens the door for diversity. (Reimers et al., 2013). Kuwait follows a secular legal system, which is a mix of English, French and Egyptian law. It experienced a period of geopolitical instability and an economic crisis in the 1980's and 1990's. It has the highest literacy in the Arab world since it provides free education to Kuwaiti nationals. Regarding economic conditions, Kuwait has crude oil reserves, which are estimated to be $10 \%$ of the world's reserves. It has huge foreign investments in Europe, United States and Asia. In 2015, the holdings were valued at $\$ 592$ billion in assets. Kuwait has adopted a new vision to be an international commercial and financial canter. Kuwaiti investment companies administer more assets than those of any other GCC countries except Saudi Arabia. In recent years, Kuwaiti investment companies have invested large percentages of their assets abroad, and their foreign assets have become substantially larger than their domestic assets. In the past five years, there has been a significant rise in entrepreneurship and small business start-ups in Kuwait.

Beyond these institutional issues, Kuwait faces many cultural and geopolitical challenges, which affect entrepreneurship. By 2020, between 80 and 100 million jobs need to be created in the Middle East North Africa (MENA) region to simply sustain current unemployment rates. Kuwait is no exception to this startling statistics. Kuwait needs to raise employment for an approximate number of 375,000 full-time positions before 2020 in order to keep step with population growth (Abdih et al., 2014; Reimers et al., 2013). The fast growth of the citizens under 25 years of age brings major issues to the fore. (Urdal and Strand 2008; the World Fact Book, 2015). Kuwait faces many political and economic challenges. Unemployment is the most significant problem, particularly for college graduates, women and youth. The situation in Kuwait requires the development of economic policies to encourage entrepreneurship. This is necessary in order to provide economic and political stability. A major component of this national goal is increasing employment in the coming decades. Hence, the Kuwaiti government is involved in different efforts to enhance small and medium enterprise sector. 
Entrepreneurship is an important vehicle towards achieving this goal (The World Bank 2014). The Kuwaiti government has exerted efforts to encourage young people to start establishing their own projects, and to provide them with the required skills to help businesses to develop. The availability of several NGOs to improve entrepreneurial skills supports the the view that developing the entrepreneurial sector is an important goal of policymakers (Masri, 2015).

\subsubsection{Literature Review}

Literature on institutional and context entrepreneurship has investigated the influence of many contextual factors, which many countries may wish to consider if they want to foster entrepreneurship (Abu-Saifan, 2012, p. 22; Carlsson et al., 2013, p. 913). Contextual factors can help establish conducive environments in which new businesses can grow. In this regard, it is possible that an individual begins setting up a new business under favourable conditions. The conditions which may contribute to this include social environment, available opportunities, sufficient entrepreneurship skills, and knowledge to start a new business and face difficulties in the start-up process (Gnyawali and Fogel, 1994, p. 45). Some researchers argue that creating such a conducive environment is more important within developing countries than developed countries due to the low levels of entrepreneurial activity and various problems for entrepreneurs (Gnyawali \& Fogel, 1994, p. 44-46; Co, 2004, p. 185-186; 52; Welter, 2011). Global Entrepreneurship Monitor (GEM) identified the effect of the political, cultural and social context on entrepreneurship. Current research is focusing on factors affecting entrepreneurial attitudes. These factors include personal experiential activities, entrepreneurship education, and exposure to entrepreneurship within the immediate family, socio-economic factors and cultural factors (Amorós et al.,, 2014, p. 10, 14, 21, 45; Salimath \& Cullen, 2010, 367-372; Tonoyan et al., 2010, p. 805; Austin et al., 2006, p. 8; Carlsson et al., 2013 , p. 925). What follows is brief definitions of these concepts.

Personal experiential activities refers to experiences gained through living in different places, traveling abroad and meeting new individuals from various cultures which is central to innovation and new venture development. Additionally, such experiences can contribute to cognitive diversity and exposure to new perspectives (Seelig, 2012; Zaki, 2012). Entrepreneurship education refers to formal development and improvement of entrepreneurial inspiration, awareness, knowledge and skills that are required in order to successfully establish and run an entrepreneurial venture (Lee et al., 2005; De Jorge-Moreno et al., 2012; Rauch and Frese, 2000). Entrepreneurship education can take various forms of university education such as courses, workshops, conferences and meetings, personal contacts relevant to entrepreneurship, seminars and training programs (Amorós et al., 2014, p. 45). It also comprises acquisition of knowledge in business, understanding the company's profile, analysis of growth, sense of ethics, capacity of seeing and seizing business opportunities which can play an important role and arouse awareness and interest in entrepreneurship (Coleman 1990; Fayolle, 2008, 2006); Gnyawali \& Fogel, 1994, p. 50, 54; Román et al., 2013, p. 152). Entrepreneurial family exposure refers to immediate family background and role models (father, mother, and other close relatives) which can affect entrepreneurial attitudes towards entrepreneurial behaviour and establish desirability to become entrepreneurs (Carr and Sequeira, 2007). Socio-economic conditions refer to social, economic and political legal 
conditions. Such factors can encourage or discourage potential entrepreneurs (Russell, 2004, p. 41). Other factors include availability of human resources and a skilled labour force, income, social mobility, population size, growth, ethnic and age structure, life expectancy, migration, lifestyle changes, education and religion (Gnyawali and Fogel, 1994, p. 46-50; David, 2013, p. 98-99; FitzRoy et al., 2012, p. 110-111; Gnyawali \& Fogel, 1994, p. 44-51; David, 2013, p. 96; FitzRoy et al., p.101; Amorós et al., 2014, p. 45:101). With regard to political-legal factors and their impact on entrepreneurship, governments set rules for entire businesses and other organisations based on particular policies and laws. General political corruption, stability and international relations of a country can influence entire organisations (David, 2013, p. 98-101; FitzRoy et al., 2012, p. 106-111; Gnyawali \& Fogel, 1994, p. 54-55). Effective institutional and legal frameworks with few barrier to prevent individuals from continue establishing business opportunities could empower the growth of new businesses (Amorós et al., 2014, p. 45; Bruce \& Mohsin, 2006; Hansson, 2012; Anokhin et al., 2010; Anokhin and Schulze, 2009, p. 465-466; Anokhin \& Schule, 2010, p. 465-466). Cultural factors refer to "collective programming of the mind distinguishing members of one group or category of people from other" (Hofstede, 2014, p. 6). Such factors include positive or negative shared values, beliefs and norms, and attitudes toward entrepreneurship. Societal attitudes towards entrepreneurship differ among cultures and their social processes, and can motivate or frustrate people to start new ventures. Entrepreneurship cannot either prosper in a society where most of its members view it with suspicion (Russell, 2004, p. 41; Lent et al., 2000; Hayton et al., 2002, p. 34, 45).

Empirical research studies on entrepreneurship are numerous. What follows is a summary of those studies.

- Ozaralli and Rivenburgh studied the entrepreneurial attitudes of senior and junior students of two Turkish and American universities. Study results showed positive attitudes towards entrepreneurship in both groups and significant correlations between entrepreneurial attitudes, tolerance, risk-taking, innovativeness and personality attributes of optimism (Ozaralli \& Rivenburgh, 2016).

- Al Hashweh's study examined the role of education in the occupied Palestinian territories in enhancing entrepreneurship spirit of school students, and the relationship between education and entrepreneurship. Research results showed positive correlations between the two variables (Al Hashweh, 2012).

- Naser \& Alomari study compared entrepreneurship characteristics of graduate students at Amman Arab University in Jordan and Damascus University in Syria. Study findings revealed significant positive correlations and differences between entrepreneurs' characteristics and entrepreneurship between both groups (Naser \& Alomari, 2011).

- Zain et al., study investigated entrepreneurship attitudes of business students in Malaysia and the role of personality traits and external conditions in this respect. Study findings showed that $67.1 \%$ of respondents showed an intention to become entrepreneurs. Moreover, influential factors included family influence (18.9\%), academicians (18\%) and business leaders (16\%). The most important influential factors were family exposure to 
entrepreneurship (60.5\%) and entrepreneurship education (50.9\%) (Zain et al., 2010).

- Regni study investigated the role of simulation as a teaching method in preparing students to become entrepreneurs. Study findings showed that simulation methods were effective in motivating students to become entrepreneurs (Regni, 2010).

- Tajeddini and Mueller studied high-tech entrepreneurs in Switzerland and the UK. Study findings showed that some entrepreneurial characteristics such as autonomy, risk-taking tolerance and locus of control are higher among UK techno-entrepreneurs, while other characteristics such as need for achievement, tolerance for ambiguity, innovativeness and confidence were higher among Swiss techno-entrepreneurs (Tajeddini \& Mueller, 2009).

- Al-Kasasbeh's study examined the attitudes of students at Petra University in Jordan towards entrepreneurship. Study findings showed that $48.4 \%$ of respondents showed intentions to become entrepreneurs, while 49.3\% did not (Al-Kasasbeh, 2008).

- Rauch \& Frese's study analyzed personality traits by matching them to the tasks of entrepreneurs. Research results revealed significant correlations between personal traits (achievement, generalised self-efficacy, innovativeness, stress tolerance, need for autonomy, proactive personality) and entrepreneurial behaviour and business creation and business success (Rauch \& Frese, 2007).

- Gürolk and Atsan's study investigated two Turkish university fourth-year cohorts entrepreneurship profiles with regard to entrepreneurship attitudes. The study results showed that entrepreneurial traits are higher for entrepreneurially inclined students in comparison with entrepreneurially non-inclined students (Gürolk \& Atsan, 2006).

- Bhandan's study examined Indian business students' desire to become entrepreneurs. Study findings showed that many personal motivating factors played a vital role towards entrepreneurship (Bhandari, 2006).

- Baum and Locke's study focused on 229 entrepreneur-chief executive officers and 106 associates within a single industry. Study results revealed that goals, self-efficacy and communicated vision have direct effects on the venture growth. Moreover, study findings showed that communicated vision and self-efficacy were related to goals, and tenacity was related to a new resource skill (Baum \& Locke, 2004).

- Christopher et al., investigated the impact of motivational characteristics on people's attitudes toward entrepreneurship, and why some people are more successful than others, and analyzed the relationships between achievement motivation and entrepreneurial behavior. Study findings showed significant correlations between achievement motivation, entrepreneurial career and entrepreneurial performance, and between both projective and self-report measures of the achievement motivation (Collins et al., 2004).

- Baron and Markman's study investigated several aspects of social competence in two different industries. Study results indicated that for both groups that social competence related positively to financial success, a high level of social capital, a favorable reputation and extensive social network, which assisted entrepreneurs in gaining access to persons 
who are considered important for their success (Baron \& Markman, 2003).

- Baron \& Markman suggested that entrepreneurs' social skills played an important role in their success. A high level of social capital, built on a favorable reputation, relevant previous experience and direct personal contacts, often assists entrepreneurs in gaining access to venture capitalists, potential customers and others. Specific social skills were the ability to make first favorable impressions, the ability to adapt to a wide range of social situations, and persuasiveness. Furthermore, study findings showed that social skills helped entrepreneurs to expand their personal networks to take advantage of opportunities to reap important benefits (Baron and Markman, 2000).

- Littunen study examined the characteristics of the entrepreneurial personality and the effects of changes in entrepreneurs' personal relationships. Study findings showed that in order to become an entrepreneur and to act as an entrepreneur, it is important to include aspects of the entrepreneur in the learning process, which has an effect on the personality characteristics of the entrepreneur (Littunen, 2000).

- Robinson et.al. Studied the entrepreneurial characteristics of 63 undergraduate students using the Attitude Orientation (AO) scale. Study findings revealed important differences between known groups for the entire four EO subscales (personal control, self-esteem, achievement and innovation (Robinson et al., 1991).

- Begley and Boyd's study examined the prevalence of five psychological attributes for a sample of 239 members from the Smaller Business Association of New England established entrepreneurs. The examined attributes included need for achievement, locus of control, risk-taking tolerance, tolerance of ambiguity and type of behavior. Moreover, the study investigated the attributes, which distinguish entrepreneurs from non-entrepreneurs. Study results showed that entrepreneurs scored significantly higher than non-entrepreneurs on three dimensions: the need for achievement, risk-taking tolerance and tolerance of ambiguity (Begley \& Boyd, 1987).

The above literature review shows that extensive research has investigated entrepreneurship from many perspectives and in different settings. Nonetheless, to the best knowledge of the present researcher, no study examined the relationships between university business students' entrepreneurship attitudes, individual characteristics and contextual factors in Kuwait. This gap justifies conducting this study which constitutes a contribution to the literature.

Based upon the conceptual framework and surveyed literature review, what follows are the study questions and hypotheses:

1.6.7 Study Questions:

1. Do CBA students intend to become entrepreneurs after graduation?

2. How positive are individual characteristics of CBA students?

3. How positive are contextual conditions of CBA students?

4. Does CBA offer relevant entrepreneurship education? 
5. Does CBA provide incentives and business incubators to encourage students to be entrepreneurs?

6. Are there correlations between students' attitudes towards entrepreneurship, individual, demographic characteristics, and contextual conditions?

\subsubsection{Study Hypotheses}

H0.1 There are no significant differences between students' attitudes towards entrepreneurship and individual characteristics.

H0.2 There are no significant differences between students' attitudes towards entrepreneurship and contextual factors.

H0.3 There are no significant differences between students' attitudes towards entrepreneurship and demographic factors (major, gender, and nationality.

\subsection{Methodology}

The study followed a descriptive analytical approach using primary and secondary sources. The primary research tool was a structured questionnaire. Secondary data was derived from reviewing literature including books, journal articles and the World Wide Web.

\section{Study Findings}

\subsection{Study Population and Sample}

Table 1. Sample Profile

\begin{tabular}{|c|c|c|}
\hline Demographic Characteristics & Frequency & Percent \\
\hline \multicolumn{3}{|l|}{ Major } \\
\hline Public Administration & 41 & $06.9 \%$ \\
\hline Business \& Marketing & 167 & $28.3 \%$ \\
\hline Economics & 26 & $04.4 \%$ \\
\hline Accounting & 237 & $40.1 \%$ \\
\hline QMIS & 70 & $11.8 \%$ \\
\hline Finance \& Financial Institutions & 50 & $08.5 \%$ \\
\hline \multicolumn{3}{|l|}{ Gender } \\
\hline 1. Male & 224 & $37.9 \%$ \\
\hline 2. Female & 367 & $62.1 \%$ \\
\hline \multicolumn{3}{|l|}{ Nationality } \\
\hline 1. Kuwaitis & 409 & $69.2 \%$ \\
\hline 2. Non Kuwaitis & 182 & $30.8 \%$ \\
\hline Total & 591 & $100 \%$ \\
\hline
\end{tabular}




\section{Macrothink}

Journal of Corporate Governance Research

ISSN 1948-4658

2019, Vol. 3, No. 1

The study population consisted of 1324 third and fourth-year CBA students in the fall of 2018. The selected sample was a random stratified sample consisting of 600 students, which comprised $45 \%$ of the total population, and met statistical standards. The researcher and two trained assistants distributed questionnaires and collected 596 completed questionnaires, represented a 98\% response rate. Descriptive statistics as shown in Table 1 showed the sample profile. According to major, $40.1 \%$ were accounting, $28.3 \%$ business and marketing, $11.8 \%$ QMIS, 8.5\% finance and financial institutions, 6.9\% public administration, and 4.4\% economics. With regard to gender, $62.1 \%$ were females, and $37.9 \%$ males. Regarding nationality, $69.2 \%$ were Kuwaitis, and 30.8 non-Kuwaitis.

\subsection{Data Collection and Scale of Measurement}

Table 2. References on Individual Characteristics and Contextual Conditions

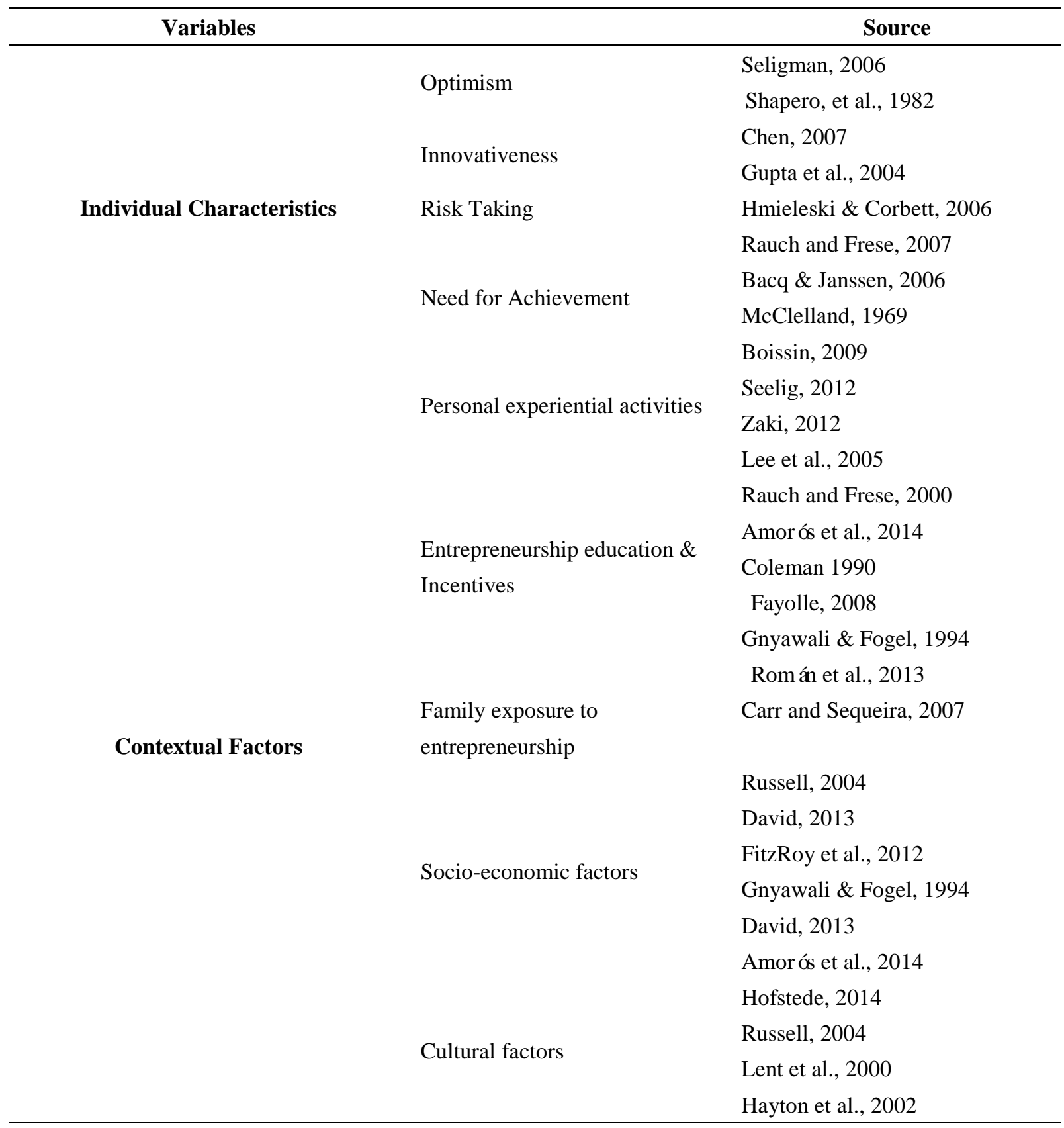




\section{Ml Macrothink}

Journal of Corporate Governance Research

ISSN 1948-4658

2019, Vol. 3, No. 1

Measurement means setting rules for assigning numbers to objects in such a way as to represent quantities of attributes (Hair et al., 2010). Items and scales were as follows. Demographic information of the questionnaire included questions about students' major, gender and nationality. The dependent variable was students' attitudes towards entrepreneurship. Independent variables included individual characteristics and contextual conditions. Table 2 shows sources of data concerning variables.

The rationale for focusing on junior and senior CBA students was the assumption that they were exposed to courses including entrepreneurship. The questionnaire consisted of three parts. The first part included three demographic items. The second part consisted of 40 items: 17 items measured individual characteristics (optimism, innovativeness, risk-taking, and need for achievement) and 20 items measured contextual factors (personal experiential activities, entrepreneurship education, immediate family experiences in entrepreneurship, socio-economic conditions and cultural factors). There were three close-end and two open-ended questions about facilities and obstacles to entrepreneurship opportunities.

The face validity of the questionnaire was ensured through presenting the questionnaire to five faculty members at KU. The final format of the questionnaire was modified to respond to referees' comments and suggestions. Additionally, a pilot study was administered on 25 CBA students and was repeated after two weeks to assure stability. Items of the questionnaire were measured on a five-point Likert scale (1) "strongly disagree," (2) "disagree," (3) "neutral,", (4) "'agree,' and (5) "strongly agree'. When measuring items, respondents were asked about their degree of agreement or disagreement. Calculated weights of respondents' answers on a five-point-Likert's scale were interpreted as follows: 3 or less meant low level, 3-3.5 medium level, 3.51-3.99 high level, and 4 and above very high level. Cronbach alpha was conducted to ensure internal consistency for all questions. Table 3 showed that Cronbach's alpha for all questions was 0.82 which indicated a high internal consistency as, most often, the measure of reliability ranged from $0-1$ with values ranging from 0.60 to 0.70 as the lower limit of acceptability (Streiner, 2003: 90-103).

Table 3. Cronbach's Alpha

\begin{tabular}{lc}
\hline Optimism & 0.70 \\
Innovation & 0.61 \\
Risk taking & 0.68 \\
Achievement & 0.72 \\
Personal experiential activities & 0.69 \\
entrepreneurship education & 0.77 \\
Family experiences in entrepreneurship & 0.87 \\
Social \& economic conditions & 0.67 \\
Cultural factors questions & 0.66 \\
All together & $\mathbf{0 . 8 2}$ \\
\hline
\end{tabular}




\subsection{Discussion: Data Analysis and Results}

The researcher used descriptive statistical methods included frequencies, percentages, means and standard deviations. Inferential statistics included ANOVA, correlation and Chi Square tests. Version 25 of SPSS software was used. After analysing data, the study findings were as follows:

\subsection{Students’ Intentions towards Entrepreneurship}

In response to the first question regarding students' entrepreneurship intentions, the study results showed (see table 4 ) that $75.3 \%$ of students showed positive intentions to become entrepreneurs, $24.4 \%$ did not, and .03 were undecided.

Table 4. Students' Attitudes Towards Entrepreneurship

\begin{tabular}{lcc}
\hline Intend to be entrepreneurs & Frequency & Percent \\
\hline Yes & 445 & $75.3 \%$ \\
No & 144 & $24.4 \%$ \\
Undecided & 02 & $00.3 \%$ \\
TOTAL & $\mathbf{5 9 1}$ & $\mathbf{1 0 0 \%}$ \\
\hline
\end{tabular}

These results are similar to Ozaralli \& Rivenburgh's study of the attitudes of Turkish and American students, Zain et. al's study of business students' attitudes in Malaysia and Gürolk \& Atsan' study of fourth year Turkish university students, but different from the results of Al-Kasasbeh's and other studies (Al-Kasasbeh, 2008; Ozaralli \& Rivenburgh, 2016; Zain et al., 2010; Gürolk \& Atsan, 2006;).

\subsection{Positivity of Individual Characteristics of CBA Students}

In response to the second question regarding individual characteristics, data analysis of questions $1-17$ (as shown in table 5) showed high means. On a five-point scale, Optimism scored 3.91, innovation 3.55, risk-taking 3.70 and need for achievement 3. 98. These results reflected very high positive qualities of the individual characteristics of students.

Table 5. Calculated Means and Standard Deviations of Individual Characteristics

\begin{tabular}{llccccc}
\hline Statistics & Optimism & Innovation & Risk taking & $\begin{array}{c}\text { N. for } \\
\text { achievement }\end{array}$ & $\begin{array}{c}\text { Overall } \\
\text { Mean }\end{array}$ \\
\hline CBA & Mean & 3.91 & 3.55 & 3.70 & 3.98 & 3.79 \\
& Std. Deviation & .65338 & .79589 & .85140 & .77184 & .63886 \\
\hline
\end{tabular}

Among examined individual characteristics, optimism and need for achievement scored highly, as shown in Table 5. This can be explained by the favourable economic conditions in Kuwait, 
which motivate students to be hopeful, to look for a good future and to depend on themselves in creating job opportunities by starting up their own projects. The research findings are similar to other research findings, which showed the importance of individual characteristics and attitudes towards entrepreneurship (Tajeddini \& Mueller, 2009; Bhndari, 2006; Littunen, 2000; Robinson et al., 19991; Begley \& Boyd, 1987; Rauch, 2007)

\subsection{Positivity of Contextual Conditions of CBA Students}

In response to the third question regarding contextual factors and their influence on students' attitudes towards entrepreneurship, data analysis showed that they were very positive. Calculated means of contextual factors, measured on a five-point scale, as shown in table 6 , were 3.78 for personal experience, 3.14 for entrepreneurship education, 3.44 for family experiences in entrepreneurship, 3.24 for socio-economic conditions, and 3.64 for cultural factors, with a 3.4518 overall mean.

Table 6. Calculated Means and Standard Deviations of Contextual Factors

\begin{tabular}{llcccccc}
\hline Statistics & $\begin{array}{c}\text { Personal } \\
\text { Exp. }\end{array}$ & $\begin{array}{c}\text { Entrep. } \\
\text { Edu. }\end{array}$ & $\begin{array}{c}\text { Family } \\
\text { Exp. }\end{array}$ & $\begin{array}{c}\text { Socio-economic } \\
\text { factors }\end{array}$ & $\begin{array}{c}\text { Cult. } \\
\text { Factors }\end{array}$ & $\begin{array}{c}\text { Overall } \\
\text { Mean }\end{array}$ \\
\hline C & Mean & 3.78 & 3.14 & 3.44 & 3.24 & 3.64 & 3.45 \\
B & Std. & .86116 & .86094 & .95718 & .88430 & .81419 & .66866 \\
A & Deviation & & & & & & \\
\hline
\end{tabular}

Calculated means of contextual factors showed higher levels of personal experiential activities and cultural factors in comparison with other factors. This result might be explained by the fact that most Kuwaitis have chances to travel and visit other countries almost on yearly basis, giving them opportunities to gain meaningful experiences. Likewise, cultural factors emphasized entrepreneurship and encouraged youth to take risks and learn from experiences. Socio-economic conditions in Kuwait are also conducive to entrepreneurship because Kuwaitis are business-oriented. They were involved in businesses seventy years ago before discovering oil. To sum up, the study findings showed that individual's characteristics and contextual factors were positive and conducive towards entrepreneurship attitudes. The results are similar to other research findings, which show the importance of personal characteristics in influencing attitudes towards entrepreneurship (Baum \& Locke, 2004; Baron \& Markman, 2003; Collins et al., 2004; Christopher et al., 2004).

\subsection{Entrepreneurship Education at CBA}

In response to the study's fourth question regarding entrepreneurship education at CBA, data analysis of responses showed that $70.7 \%$ of students, as shown in table 7 , believed that CBA provided entrepreneurship courses, while $29.3 \%$ thought that CBA did not. With regard to forms of entrepreneurship education, the responses showed that CBA organized workshops, seminars and other events related to entrepreneurship. These results are similar to Al-Hashweh's study, which showed positive correlations between entrepreneurial education 


\section{Macrothink}

Journal of Corporate Governance Research

ISSN 1948-4658

2019, Vol. 3, No. 1

of students in occupied Palestinian territories and attitudes towards entrepreneurship and Regni's study, which showed that simulation methods of entrepreneurship education were effective in motivating students to become entrepreneurs (Al Hashweh, 2012; Regni, 2010).

Table 7. Availability of Entrepreneurship Education at CBA

\begin{tabular}{lccc}
\hline Answer & Frequency & Percent \\
\hline Yes & 418 & $70.7 \%$ \\
No & 173 & $29.3 \%$ \\
& & $\mathbf{5 9 1}$ & $\mathbf{1 0 0 \%}$ \\
\hline
\end{tabular}

Moreover, data analysis showed that CBA exerted efforts in reviewing and updating curricula periodically. Table 8 show that $79.9 \%$ of respondents agreed that CBA revised and updated curricula while $20.3 \%$ did not.

Table 8. Updating Curricula at CBA

\begin{tabular}{|c|c|c|}
\hline Answer & Frequency & Percent \\
\hline Yes & 471 & $79.9 \%$ \\
\hline No & 120 & $20.3 \%$ \\
\hline Total & 591 & $100 \%$ \\
\hline
\end{tabular}

\subsection{Incentives and Business Incubators at CBA}

In response to the study's fifth question regarding incentives and business incubators, data analysis, as shown in table 9 , shows that $34.5 \%$ of respondents mentioned that CBA provided incentives and business incubators while $65.5 \%$ said it did not.

Table 9. CBA Providing Incentives and Business Incubators

\begin{tabular}{lccc}
\hline Answer & & Frequency & Percent \\
\hline Yes & 204 & $34.5 \%$ \\
No & 387 & $65.5 \%$ \\
& & & $100 \%$ \\
\hline
\end{tabular}

\subsection{Relationships between Demographic Factors and Entrepreneurship Attitudes.}

In response to the sixth question regarding demographic factors and attitudes towards entrepreneurship. Table10 results shows no significant correlations between students' major and attitudes. This means that attitudes were not related to students' major and that individual characteristics and contextual factors were more influential than demographic factors. These 
results were similar to the findings of Nasser \& Alomari study which revealed significant positive correlations between entrepreneurs' characteristics and entrepreneurship (Naser \& Alomari, 2011).

Table 10. Pearson Correlation between Students' Attitudes towards Entrepreneurship and Major

\begin{tabular}{cc}
\hline Pearson Correlation & .009 \\
\hline Sig. (2.tailed) & .826 \\
$\mathrm{~N}$ & 591 \\
\hline
\end{tabular}

With regard to relationships between students' attitudes and nationality, the study results showed no significant correlation between them as shown in table 11.

Table 11. Pearson Correlation between Students' Attitudes towards Entrepreneurship and Nationality

\begin{tabular}{cc}
\hline Pearson Correlation & -.034 \\
\hline Sig. (2.tailed) & .415 \\
$\mathrm{~N}$ & 591 \\
\hline
\end{tabular}

Likewise, with respect to gender, study results showed no significant correlation between students' attitudes and gender as shown in table 12.

Table 12. Pearson Correlation between Students' Attitudes towards Entrepreneurship and Gender

\begin{tabular}{cc}
\hline Pearson Correlation & -.009 \\
\hline Sig. (2.tailed) & .832 \\
$\mathrm{~N}$ & 591 \\
\hline
\end{tabular}

The above-mentioned results showed no significant correlations between students' attitudes and demographic factors in contrast to individual characteristics and contextual factors. One way to explain this result is that Kuwait, like many countries in the region, is passing through critical conditions and experiencing narrowing job opportunities, particularly in the public sector, which has motivated students to think of starting their own projects after graduation. Conducive economic conditions in Kuwait support this orientation for students to depend on themselves in creating their own jobs after they graduate. Kuwait as an oil producing country, even before the decreasing oil prices of the last decade, used to have yearly budget surpluses in most years, which allowed the government to allocate funds to support entrepreneurs. At the 
same time, the new economic conditions in Kuwait have left very limited room for the government to provide job opportunities in the public sector.

\subsection{Testing Hypotheses}

The core mechanism of hypotheses testing is to identify whether the actual sample mean has deviated from the mean of the hypothesized sampling distribution by which a certain value will prove that it is wrong. In order to calculate this deviation, the researcher has chosen the most common decision criterion, which is a significance level at less or equal than 0.05 , it presents a critical probability in choosing between the null hypothesis and the alternative hypothesis. The assumption was the probability of observed data was smaller than the level of significance, which suggests the null hypothesis should be rejected and vice versa.

H0.1. There are no significant differences between individual characteristics, which included optimism, innovativeness, risk-taking tolerance, and the need for achievement, and students' attitudes towards entrepreneurship.

To test the hypothesis, one-way analysis of variance (ANOVA) was conducted. As shown in table 13, the results showed no significant differences in students' ambition, risk taking and need for achievement, but differences only in innovation.

Table 13. One Way ANOVA Test of Differences between Students' Intentions Due to Individual Characteristics

\begin{tabular}{llccccc}
\hline & & Sum of & df. & Mean Squares & F & Sig. \\
& & Squares & & & & \\
\hline Ambition & Between Groups & 2.935 & 13 & 226 & 1.281 & .230 \\
& Within Groups & 26.957 & 153 & 176 & & \\
& Total & 29.892 & 166 & & & \\
& Between Groups & 8.611 & 16 & .538 & 3.793 & .000 \\
& Within Groups & 21.281 & 150 & & & \\
Innovation & Total & 29.892 & 166 & & & \\
Risk taking & Between Groups & 3.773 & 13 & .290 & 1.700 & -.066 \\
& Within Groups & 26.119 & 153 & 171 & & \\
Need & Total & 29.892 & 166 & & & \\
Achievement & Between Groups & 3.773 & 13 & .290 & 1.700 & .066 \\
& Within Groups & 26.119 & 153 & .171 & & \\
& Total & 29.892 & 166 & & & \\
& Within Groups & 8.367 & 90 & .093 & & \\
& Total & 29.892 & 166 & & & \\
\hline
\end{tabular}

H0.2. There are no significant differences between contextual factors (personal experiential activities, entrepreneurship education, entrepreneurial family exposure, socio-economic conditions and cultural factors) and students' attitudes towards entrepreneurship. 


\section{Macrothink}

Journal of Corporate Governance Research

ISSN 1948-4658

2019, Vol. 3, No. 1

To test the hypotheses, One Way ANOVA analysis was conducted. The results as shown in the table 14, showed significant differences in personal experiential activities, entrepreneurship education, immediate family experiences and socio-economic conditions in influencing students' attitudes towards entrepreneurship, but not in cultural factors.

Table 14. One Way ANOVA Test of Differences between Students' Attitudes Due to Contextual Conditions

\begin{tabular}{|c|c|c|c|c|c|c|}
\hline $\begin{array}{l}\text { Contextual } \\
\text { Conditions }\end{array}$ & \multicolumn{6}{|c|}{ Conditions } \\
\hline Personal & Between Groups & 6.802 & 13 & .523 & 3.467 & .000 \\
\hline \multirow[t]{2}{*}{ Experiences } & Within Groups & 23.090 & 153 & 151 & & \\
\hline & Total & 29.892 & 166 & & & \\
\hline Entrepreneurship & Between Groups & 6.783 & 17 & .399 & 2.573 & .001 \\
\hline \multirow[t]{2}{*}{ Education } & Within Groups & 23.109 & 149 & 151 & & \\
\hline & Total & 29.892 & 156 & & & \\
\hline Family & Between Groups & 4.700 & 16 & .294 & 1.740 & .043 \\
\hline Experiences in & Within Groups & 25.192 & 150 & 118 & . & \\
\hline Entrepreneurship & Total & 29.892 & 166 & & & \\
\hline Socio-Economic & Between Groups & 4.718 & 18 & .295 & 1.757 & .042 \\
\hline \multirow[t]{2}{*}{ Conditions } & Within Groups & 25.174 & 150 & .168 & & \\
\hline & Total & 29.892 & 166 & & & \\
\hline \multirow[t]{5}{*}{ Cultural Factors } & Between Groups & 2.502 & 15 & .167 & .920 & .544 \\
\hline & Within Groups & 27.390 & 151 & .181 & & \\
\hline & Total & 20.892 & 166 & & & \\
\hline & Within Groups & 19.932 & 126 & .158 & & \\
\hline & Total & 29.892 & 166 & & & \\
\hline
\end{tabular}

This result implies that contextual factors were influential in affecting students' attitudes towards entrepreneurship. This result was supported by the findings of many studies (Ozaralli \& Rivenburgh; 2016; Baron \& Markman, 2012; Gürolk \& Atsan, 2006; Tajeddini \& Mueller, 2009; Naser \& Alomari, 2011).

H0.3. There are no significant differences between students' attitudes towards entrepreneurship due to major, gender and nationality.

To test this hypothesis, Chi-Square test was conducted for the three sub- hypotheses.

H0.3.1 There are no significant differences in students' attitudes towards entrepreneurship due to major.

To test the hypothesis Chi-Square test was conducted. The results as shown in Table 15 indicate that students' attitudes towards entrepreneurship differ significantly according to students' major. This result did not support the null hypotheses which means that students' major affected attitudes towards entrepreneurship. 
Table 15. Chi-Square Test

\begin{tabular}{lccc}
\hline & Value & Df & Asymptotic Significance (2-sided) \\
\hline Pearson Chi-Square & $25.326^{\mathrm{a}}$ & 10 & .005 \\
Likelihood Ratio & 22.747 & 10 & .012 \\
Linear-by-Linear Association & .048 & 1 & .826 \\
N of Valid Cases & 591 & & \\
\hline
\end{tabular}

a. 6 cells $(33.3 \%)$ have expected count less than 5. The minimum expected count is .09 .

This result showed CBA students' attitudes towards entrepreneurship differ significantly due to major.

H0.3.2 There are no significant differences between students' attitudes towards entrepreneurship due to gender.

To test the hypothesis, Chi-Square test was conducted. Results as shown in Table 16 indicate that students' attitudes towards entrepreneurship do not differ significantly according to gender. This result supports the null hypothesis.

Table 16. Chi-Square Test

\begin{tabular}{lccc}
\hline & Value & Df & Asymptotic Significance (2-sided) \\
\hline Pearson Chi-Square & $1.634^{\mathrm{a}}$ & 2 & .442 \\
Likelihood Ratio & 2.316 & 2 & .314 \\
Linear-by-Linear Association & .45 & 1 & .832 \\
N of Valid Cases & 591 & & \\
\hline
\end{tabular}

a. 2 cells $(33.3 \%)$ have expected count less than 5. The minimum expected count is .76 .

H0 3.3. There are no significant differences between students' attitudes towards entrepreneurship due to nationality.

To test the hypothesis Chi-Square test was conducted. The results as shown in Table 17 indicate that students' attitudes towards entrepreneurship do not differ significantly according to nationality. This result supports the null hypothesis.

Table 17. Chi-Square Test

\begin{tabular}{lccc}
\hline & Value & Df & Asymptotic Significance (2-sided) \\
\hline Pearson Chi-Square & $1.162^{\mathrm{a}}$ & 2 & .559 \\
Likelihood Ratio & 1.746 & 2 & .418 \\
Linear-by-Linear Association & .665 & 1 & .415 \\
N of Valid Cases & 591 & & \\
\hline
\end{tabular}

a. 2 cells $(33.3 \%)$ have expected count less than 5. The minimum expected count is .62 . 


\section{Conclusions and Recommendations}

\subsection{Conclusions}

Based on the study findings, the conclusions and recommendations are as follows:

1. The majority of CBA students (75.3\%) showed an intention to become entrepreneurs, while a minority $(24.4 \%)$ did not, and .03 were undecided.

2. Most of students (70.7\%) believed that CBA offered entrepreneurship courses while $29.3 \%$ thought that it did not.

3. $70.7 \%$ of CBA students responded that CBA organized different forms of entrepreneurship education, including workshops, seminars, training programs and other events related to entrepreneurship, while $29.3 \%$ did not. Moreover, $79.9 \%$ of students mentioned that CBA reviewed and updated curricula periodically, while $20.3 \%$ did not agree.

4. A minority of students $(34.5 \%)$ mentioned that CBA provided incentives and business incubators, while $65.5 \%$ did not agree.

5. There were no significant correlations between major, gender, nationality and students' attitudes toward entrepreneurship.

6. Respondents showed high positive levels of optimism (3.91), innovation (3.55), risk taking (3.70) need for achievement (3.98) on a five-point scale. This result reflected very high positive qualities of individual characteristics, which are influential on students' attitudes towards entrepreneurship.

7. Respondents indicated positive contextual conditions towards attitudes towards entrepreneurship. On a five-point scale, means were (3.78) for personal experience, 3.14 for entrepreneurship education, 3.44 for family experiences in entrepreneurship, 3.24 for socio-economic conditions, 3.64 for cultural factors and 3.45 overall mean when all factors were taken together.

8. There were no significant differences in individual's ambition, risk taking and need for achievement. The only significant difference was in innovation.

9. There were significant differences in students' personal experiential activities, entrepreneurship education, immediate family experiences, and socio-economic conditions in influencing students' attitudes towards entrepreneurship. However, results showed no significant differences in cultural factors.

10. There were no significant differences in students' attitudes towards entrepreneurship due to gender and nationality, however, there were differences based on major.

\subsection{Recommendations}

Based on the study conclusions, we submit the following recommendations:

1. CBA academic departments should consider putting more emphasis on 
entrepreneurship because the study results showed that the students' major influenced their attitude toward entrepreneurship.

2. CBA should exert more efforts to provide more incentives plans and business incubators in order to influence students to start setting up projects and businesses after graduation. This is necessary because $65.5 \%$ of students thought that available incentives and business incubators were unsatisfactory while only $34.5 \%$ thought they were satisfactory.

3. It is important that CBA should develop, review programs to make them responsive to changing economic, social conditions and trends in Kuwait in order to make them attractive to students.

4. More research should be conducted on students' attitudes toward entrepreneurship in public and private universities in Kuwait. Additionally, students' involvement in such research might encourage them to become entrepreneurs after graduation.

\section{Acknowledgement}

Special thanks to the Research Administration of Kuwait University which provided a grant for the study, Project No.IU01/17

\section{References}

Abdih, Yasser, Andrea Gamba \& Rafik Selim. (2014). Jordan: Selected Issues. International Monetary Fund. 1 June 2014. Web. 2 Oct. 2015.

Abu-Saifan, S. (2012). Social Entrepreneurship: Definition and Boundaries. Technology Innovation Management Review, 22-27. https://doi.org/10.22215/timreview/523

Ajzen, I. (2005). Attitudes, Personality and Behavior (2nd ed.). England: Open University Press (McGraw-Hill).

Ajzen, I. (2002). Perceived behavioral control, self-efficacy, locus of control, and the theory of planned behavior. Journal of Applied Social Psychology, 32, 1-20. https://doi.org/10.1111/j.1559-1816.2002.tb00236.x

Ajzen. I. (1991). The Theory of Planned Behavior. Organizational Behavior, 50(2), 179-211. https://doi.org/10.1016/0749-5978(91)90020-T

AL ASH-Shakyh, Malik. (2018). Arab countries marked by youth unemployment. Step Feed.

Al-Hashweh, M. (2012). Education for Entrepreneurship in Palestine. (in Arabic). Ramallah. Palestine Institute for Economic Policies.

AlKasasbeh, M. (2008). The Preparedness toward Entrepreneurship: An Exploratory Study of 
Petra University Students". A Conference Paper submitted to the Ninth Conference of Arab Organization for Administrative Sciences on 9-11 November. (In Arabic).

Alvarez, S. A., \& Barney, J. B. (2007). Discovery and Creation: Alternative Theories of Entrepreneurial Action. Strategic Entrepreneurship Journal, 1(1-2), 11-26. https://doi.org/10.1002/sej.4

AL Zu'bi, Bashar. (2018). Entrepreneurship can help the youth create jobs. The Jordan Times, Apr 23.

Amari, Farouk, Abbes, Ikram, and Boudabbous, Sami (2014). The influence of individual factors on the entrepreneurial intention. International Journal of Managing Value and Supply Chains (IJMVSC), 5(4), 47-57. https://doi.org/10.5121/ijmvsc.2014.5404

Amorós, J. E., \& Bosma, N. (2014). Global Entrepreneurship Research Association. Global Entrepreneurship Monitor. 2013 Global Report. Fifteen years of assessing.

Anokhin, S., \& Schulze, W. S. (2009). Entrepreneurship, innovation, and corruption. Journal of Business Venturing, 24(5), 465-476. https://doi.org/10.1016/j.jbusvent.2008.06.001

Audretsch, D. (2012). Entrepreneurship research. Management Decision, 50(5), 755-764. https://doi.org/10.1108/00251741211227384

Austin, J., Stevenson, H., \& Wei-Skillern, J. (2006). Social and Commercial Entrepreneurship: Same, Different, or Both? Entrepreneurship: Theory \& Practice, 30(1), 1-22. https://doi.org/10.1111/j.1540-6520.2006.00107.x

Bacq, S. S., \& Janssen, F. F. (2011). The multiple faces of social entrepreneurship: A review of definitional issues based on geographical and thematic criteria. Entrepreneurship \& Regional Development, 23(5/6), 373-403. https://doi.org/10.1080/08985626.2011.577242

Baron \& Markman (2003). Beyond social capital: the role of entrepreneurs' social competence in their financial success. Journal of Business Venturing, 18(1), 41-60. https://doi.org/10.1016/S0883-9026(00)00069-0

Baron, Robert A., \& Markman, Gideon D. (2000). Beyond social capital: How social skills can enhance entrepreneurs' success. ACAD MANAGE PERSPECT, 14(1), 106-116. https://doi.org/10.5465/ame.2000.2909843

Baum, J. R., \& Locke, E. A. (2004). The Relationship of Entrepreneurial Traits, Skill, and Motivation to Subsequent Venture Growth. Journal of Applied Psychology, 89(4), 587-598. https://doi.org/10.1037/0021-9010.89.4.587

Begley (1987). T. Psychological characteristics associated with performance in entrepreneurial firms and smaller businesses. Journal of Business Venturing, 2(1), 79-93. https://doi.org/10.1016/0883-9026(87)90020-6

Bhandari, N. C. (2006). Intentions for Entrepreneurship among Students in India. The $\begin{array}{lll}\text { Journal for } & \text { Entrepreneurship, } & 169-179 .\end{array}$ 
https://doi.org/10.1177/097135570601500204

Bills, Nicole. (2015). "Education and Entrepreneurship in Amman, Jordan" Senior Theses. University of South Carolina. Scholar Commons Paper 49. Winter, 1-63.

Boissin, J. P., Chollet, B., \& Emin, S. (2009), Les déterminants de l'intention de créer une entreprise chez les étudiants: un test empirique. M@n@gement, 12(1), 28-51. https://doi.org/10.3917/mana.121.0028

Bornstein, D. (2004). How to Change the World. Social Entrepreneurs and the Power of New Ideas (1st ed.). New York: Oxford University Press.

Boyd, N. G., \& Vozikis, G. S. (1994). The Influence of Self -Efficiency on the Development of Entrepreneurial Intentions and Actions. Entrepreneurship: Theory \& Practice, 18(4), 63-77. https://doi.org/10.1177/104225879401800404

Bruce, D., \& Mohsin, M. (2006). Tax policy and entrepreneurship: New time series evidence. Small Business Economics, 26(5), 409-425. https://doi.org/10.1007/s11187-005-5602-8

Burns, P. (2011). Entrepreneurship and small business. Start-up growth and maturity (3rd ed.). Hampshire: Palgrave Macmillan.

Cantillon, R. (2010). An Essay on Economic Theory (C. Saucier \& M. Thornton, Trans.). Alabama: Ludwig von Mises Institute. E-Book.

Carland, J. W., Hoy, F., Boulton, W. R., \& Carland, J. C. (1984). Differentiating Entrepreneurs from Small Business Owners: A Conceptualization. Academy of Management Review, 9(2), 354-359. https://doi.org/10.5465/amr.1984.4277721

Carlsson, B., Braunerhjelm, P., McKelvey, M., Olofsson, C., Persson, L., \& Ylinenpää, H. (2013). The e ving domain of entrepreneurship research. Small Business Economics, 41(4), 913-930. https://doi.org/10.1007/s11187-013-9503-y

Carr, J. C., \& Sequeira, J. M. (2007). Prior family business exposure as intergenerational influence and entrepreneurial intent: a theory of planned behavior approach. Journal of Business Research, 60, 1090-1098. https://doi.org/10.1016/j.jbusres.2006.12.016

Chen, M. H. (2007). Entrepreneurial leadership and new ventures: creativity on entrepreneurial teams. Creativity and Innovation Management, 16(3), 239-249. https://doi.org/10.1111/j.1467-8691.2007.00439.x

Choi, Daejeong, In-Sue Oh \& Amy E. Colbert. (2015). Understanding Organizational Commitment: A Meta-Analytic Examination of the Roles of the Five-Factor Model of Personality and Culture. Journal of Applied Psychology, 100(5), 1542-1567. https://doi.org/10.1037/ap10000014

Choi, N., \& Majumdar, S. (2013). Social entrepreneurship as an essentially contested concept: Opening a new avenue for systematic future research. Journal of Business Venturing, 29(3), 363-376. https://doi.org/10.1016/j.jbusvent.2013.05.001 


\section{I Macrothink}

Journal of Corporate Governance Research ISSN 1948-4658

Co, M. J. (2004). The Formal Institutional Framework of Entrepreneurship in the Philippines: Lessons for Developing Countries. Journal of Entrepreneurship, 13(2), 185-203. https://doi.org/10.1177/097135570401300204

Collins, Christopher J. et al. (2004). The Relationship of Achievement Motivation to Entrepreneurial Behavior: A Meta-Analysis. Human Performance, 17(1), 95-117. Consortium. https://doi.org/10.1207/S15327043HUP1701_5

Corner, P., \& Ho, M. (2010). How Opportunities Develop in Social Entrepreneurship. Entrepreneurship, Theory \& Practice, 34(4), 635-659. https://doi.org/10.1111/j.1540-6520.2010.00382.x

David, F. R. (2013). Strategic Management Concepts and Cases. A Competitive Advantage Approach (14th ed.). Edinburgh Gate: Pearson Education Limited.

De Jorge-Moreno, J., Castillo, L. L., \& Triguero, M. S. (2012). The effect of business and economics education programs on student's entrepreneurial intention. European Journal of Training and Development, 36(4), 409-425. https://doi.org/10.1108/03090591211220339

Dees, J. (2001). The Meaning of 'Social Entrepreneurship. Duke University, Durham.

Dees, J. (2007). Taking Social Entrepreneurship Seriously. Society, 44(3), 24-31. https://doi.org/10.1007/BF02819936

Drucker, P. F. (1985a). The discipline of innovation. Harvard Business Review, 63(3), 67-72.

Drucker, P. F. (1985b). Innovation and Entrepreneurship: Practice and Principles (1st ed.). Oxford: Elsevier.

Dyer, Jeffrey. H. et al. (2009). The Innovator's DNA. Harvard Business Review. December.

Eisenmann, Thomas R. (2013). Entrepreneurship: A Working Definition. Harvard Business Review, January 10.

Engle, R. L., Dimitriadi, N., Gavidia, J. V., \& Schlaegel, C. (2010). Intrepreneurial intent: a twelve country evaluation of Ajzen's model of planned behavior. International Journal of Entrepreneurial Behavior and Research, 16(1), 35-57. https://doi.org/10.1108/13552551011020063

Fayolle A., \& Gailly B (2008). From craft to science. Teaching models and Learning processes in entrepreneurship education. J. Eur. Indust. Train., 32(7), 569-593. https://doi.org/10.1108/03090590810899838

FitzRoy, P. T., Hulbert, J. M., \& Ghobadian, A. (2012). Strategic Management. The challenge of creating value (2nd ed.). Abingdon: Routledge. https://doi.org/10.4324/9780203804407

Gartner, W. B. (1985). A Conceptual Framework for Describing the Phenomenon of New Venture Creation. Academy Of Management Review, 10(4), 696-706. 
https://doi.org/10.5465/amr.1985.4279094

GEM (2006). Global Entrepreneurship Monitor Report. Babson College,

GEM (2014). Key Indicators. Global Entrepreneurship Monitor.

Gladwell, Malcolm. David \& Goliath. (2013). Underdogs, Misfits, and the Art of Battling Giants. New York: Little, Brown and Company, 2013.

Gnyawali, D. R., \& Fogel, D. S. (1994). Environments for Entrepreneurship Development: Key Dimensions and Research Implications. Entrepreneurship: Theory \&Practice, 18(4), 43-62. https://doi.org/10.1177/104225879401800403

Gupta, V., MacMillan, I. C., \& Surie, G. (2004). Entrepreneurial leadership: developing and measuring a cross-cultural construct. Journal of Business Venturing, 19(2), 241-260. https://doi.org/10.1016/S0883-9026(03)00040-5

Gurol Y., \& Atsan N. (2006). Entrepreneurial characteristics amongst university Students: some insights for entrepreneurship education and Training in Turkey. Educ. Train., 48(1), 25-38. https://doi.org/10.1108/00400910610645716

Hansson, A. (2012). Tax policy and entrepreneurship: empirical evidence from Sweden. Small Business Economics, 38(4), 495-513. https://doi.org/10.1007/s11187-010-9282-7

Hattab, Hala W. (2015). Impact of Entrepreneurship Education on Entrepreneurial Intentions of University Students in Egypt. The Journal of Entrepreneurship, 23(1), 1-18. https://doi.org/10.1177/0971355713513346

Hayton, J. C., George, G., \& Zahra, S. A. (2002). National Culture and Entrepreneurship: A Review of Behavioral Research. Entrepreneurship: Theory \& Practice, 26(4), 33-52. https://doi.org/10.1177/104225870202600403

Hisrich, R. D., \& Peters, M. P. (2002). Entrepreneurship (5th ed.). New York: McGraw-Hill.

Hmieleski, K. M., \& Corbett, A. C. (2006). Proclivity for improvisation as a predictor of entrepreneurial intentions. Journal of Small Business Management, 44, 45-63. https://doi.org/10.1111/j.1540-627X.2006.00153.x

Hofstede, G. (2014a). National culture dimensions. The Hofstede Centre. Retrieved from http://geert-hofstede.com/national-culture.html.

Hofstede, G. (2014b). Country comparison. The Hofstede Centre. Retrieved from http://geert-hofstede.com/countries.html. [Retrieved 2014-04-04

Johnson, G., Scholes, K., \& Whittington R. (2011). Exploring Strategy (9th ed.). Edinburgh Gate: Pearson Education Limited.

Reynolds. PD. Et al. Kauffman (1999). Global Entrepreneurship Monitor Centre for Entrepreneurship. Babson College, Wellesley, MA.

Kolvereid, L., \& Isaksen, E. (2006). New business start-up and subsequent entry into 
self-employment. Journal of Business Venturing, 21(6), 866-885. https://doi.org/10.1016/j.jbusvent.2005.06.008

Krueger, N., Reilly, M., \& Carsrud, A. (2000). Competing models of entrepreneurial attitudes. Journal of Business Venturing, 15(5-6), 411-432. https://doi.org/10.1016/S0883-9026(98)00033-0

Lee,Sang M. et al. (2005). Impact of Entrepreneurship Education: A Comparative Study of the U.S. and Korea. The International Entrepreneurship and Management Journal, 1(1), 27-43. https://doi.org/10.1007/s11365-005-6674-2

Lekoko, M. E. et al. (2012). The effectiveness of entrepreneurship education: What Matters Most? African Journal of Business Management, 6(51), 12023-12033. https://doi.org/10.5897/AJBMx12.001

Lent, R. W., Brown, S. D., \& Hackett, G. (2000). Contextual supports and barriers to career choice: a social cognitive analysis. Journal of Counseling Psychology, 47(1), 36-49. https://doi.org/10.1037/0022-0167.47.1.36

Li, W. (2007). Ethnic entrepreneurship: studying Chinese and Indian students in the United States. Journal of Developmental Entrepreneurship, 12, 449-466. https://doi.org/10.1142/S1084946707000769

Littunen, Hannu. (2000) Entrepreneurship and the characteristics of the entrepreneurial personality, International Journal of Entrepreneurial Behavior \& Research, 6(6), 295-310. https://doi.org/10.1108/13552550010362741

Lle, Alain et Benoît Gailly (2009), Évaluation d'une formation en entrepreneuriat: prédispositions et impact sur l'intention d'entreprendre.M@n@gement, 12(3), 176-203. https://doi.org/10.3917/mana.123.0176

Lumpkin, G. T., \& Katz, J. A. (2011). An Introduction to the Special ume on Social and Sustainable Entrepreneurship. In G.T. Lumpkin, Jerome A. Katz (Ed.), Social and Sustainable Entrepreneurship (Advances in Entrepreneurship, Firm Emergence and Growth, ume 13, 201-229. https://doi.org/10.1108/S1074-7540(2011)0000013004

Mack, J., \& Pützschel, (2014). The influence of contextual factors on the entrepreneurial process. Master thesis presented at Umeå School of Business and Economics.

Masri, Munther. Case Study on Jordan, Dr. Munther Masri. (2015). Entrepreneurship Education in the Arab States. UNESCO and Strat REAL Foundation, U.K. Apr. 2010. Web. 10 Nov. 2015.

McClelland (1965). Achievement and entrepreneurship: A longitudinal study. Journal of Personality and Social Psychology, 1, 389-392. https://doi.org/10.1037/h0021956

McClelland, David C. (1987). Characteristics of Successful Entrepreneurs. The Journal of Creative Behavior, 21(3), 219-233. https://doi.org/10.1002/j.2162-6057.1987.tb00479.x

Naser, Jawdat \& AL Omari. Ghassan. (2011). Measuring Entrepreneurship Characteristics of 
Business Graduate Students and their Effect on Entrepreneurship Businesses: a Comparative Study. Journal of Damascus University of Economics and Law, 27(4), 139-168.

Niyonkuru R (2005). Entrepreneurship education at tertiary institutions in Rwanda: A situational analysis. Western Cape, University of Western Cape.

Oviatt, B. M., \& McDougall, P. (1994). Towards a Theory of International New Ventures. Journal of International Business Studies, 25(1), 45-64. https://doi.org/10.1057/palgrave.jibs.8490193

Ozaralli, Nurdan \& Rivenburgh, Nancy K. (2016). Entrepreneurial intention: antecedents to entrepreneurial behavior in the U.S.A. and Turkey. Journal of Global Entrepreneurship Research, 6(3). https://doi.org/10.1186/s40497-016-0047-x

Pihie, Z. A., \& Bagheri, A. (2011). Malay secondary school entrepreneurial, attitude orientation and entrepreneurial self-efficacy: a descriptive study. Journal of Applied Science, 11(2), 316-322. https://doi.org/10.3923/jas.2011.316.322

Rauch Andreas \& Frese, Michael. (2007). Let us put the person back into entrepreneurship research: A meta-analysis on the relationship between business owners' personality traits, business creation, and success. European Journal of Work and Organizational Psychology, 16(4), 353-385. https://doi.org/10.1080/13594320701595438

Regni, Rosalie. (2010). Entrepreneurship Methods of Preparing Students, in a Classroom Environment, through the use of Simulation, the Techniques of Opening a Small Business. The International Journal of Learning, 16(12). https://doi.org/10.18848/1447-9494/CGP/v16i12/46786

Reimers, Fernado, Paul Dyer, Suzanne Lettrick \& Maria Elena Ortega-Hesles. (2013). Unlocking Arab Youth Entrepreneurship Potential: An Evaluation of the INJAZ Al-Arab Company Program. Wamda. 2 June 2013.

Roberts, D., \& Woods, C. (2005). Changing the world on a shoestring: The concept of social entrepreneurship. University Of Auckland Business Review, 7(1), 45-51.

Robinson, Peter B. et al. (1991). An attitude approach to the prediction of entrepreneurship. Entrepreneurship Theory and Practice, Summer, 13-31. https://doi.org/10.1177/104225879101500405

Román, C., Congregado, E., \& Milán, J. M. (2013). Start-up incentives: Entrepreneurship policy or active labor market program? Journal of Business Venturing, 28(1), 151-175. https://doi.org/10.1016/j.jbusvent.2012.01.004

Russell, R. D. (2004). Cultural Influences on Entrepreneurship: Implications for the Emergence of New Ventures in Latin America. Journal of Transnational Management, 10(1), 37-59. https://doi.org/10.1300/J482v10n01_04

Rwigema, H., \& Ventor, R. (2004). Advanced Entrepreneurship. Cape Town: Oxford 
University Press.

Salimath, M. S., \& Cullen, J. B. (2010). Formal and informal institutional effects on entrepreneurship: a synthesis of nation-level research. International Journal of Organizational Analysis, 18(3), 358-385. https://doi.org/10.1108/19348831011062175

Saucier, C., \& Thornton, M. (2010). Introduction to 'An Essay on Economic Theory' (1st ed.). Alabama: Ludwig von Mises Institute.

Seligman, Martin EP. (2006). Learned Optimism: How to change your mind and your life. Vintage

Seelig, T. (2012). Ingenious: a crash course on creativity. New York: HarperCollins.

Shane, S., \& Venkataraman, S. S. (2000). The Promise of Entrepreneurship as a Field of Research. Academy Of Management Review, 25(1), 217-226. https://doi.org/10.5465/amr.2000.2791611

Shapero, A. et al. (1982). The social dimensions of entrepreneurship, Encyclopedia of entrepreneurship. Englewood Cliffs: Prentice Hall, chap. IV, IV (1982), pp. 72-90.

Short, J. C., Ketchen, J. J., Shook, C. L., \& Ireland, R. (2010). The Concept of Opportunity in Entrepreneurship Research: accomplishments and Future Challenges. Journal of Management, 36(1), 40-65. https://doi.org/10.1177/0149206309342746

Streiner, D. (2003). Starting at the beginning: an introduction to coefficient alpha and internal consistency. Journal of personality assessment, 80, 99-103. https://doi.org/10.1207/S15327752JPA8001_18

Tajeddini, Keyhan \& Mueller, Stephen L. (2009). Entrepreneurial characteristics in Switzerland and the UK: A comparative study of techno-entrepreneurs. Journal of International Entrepreneurship, 7(1). https://doi.org/10.1007/s10843-008-0028-4

The World Bank (2012). https://doi.org/10.1596/9780821395684

The World Bank (2014). Internet users (per 100 people). World Bank Data.

The World Bank. (2015). Middle East \& North Africa (developing only). Web. 20 Apr. 2015.

The World Bank. (2015). Jordan. Web. 20 Apr. 2015.

The World Factbook. (2015). Middle East: Jordan. Central Intelligence Agency. 19 Nov. 2015. Web. 22 Nov. 2015.

Thompson, N., Kiefer, K., \& York, J. G. (2011). Distinctionsnot Dichotomies. Train, 30(9), 701-720.

Tonoyan, V., Strohmeyer, R., Habib, M., \& Perlitz, M. (2010). Corruption and Entrepreneurship: How Formal and Informal Institutions Shape Small Firm Behavior in Transition and Mature Market Economies. Entrepreneurship: Theory \& Practice, 34(5), 803-831. https://doi.org/10.1111/j.1540-6520.2010.00394.x 


\section{Macrothink}

Journal of Corporate Governance Research ISSN 1948-4658 2019, Vol. 3, No. 1

Urdal, Henrik \& Håvard Strand. (2008). Youth Bulges, Democratic Elections, and Political Instability. Conference Papers -- International Studies Association (2008): 1-Academic Search Complete. Web. 12 Nov. 2015.

Venkataraman, S. (1997). The distinctive domain of entrepreneurship research: An editor's perspective. In J. Katz \& R. Brockhaus, (Ed.), Advances in entrepreneurship, firm emergence and growth. Third ume. Greenwich: CT JAI Press. pp. 119-138.

WCED (1987). Report of the World Commission on Environment and Development: our Common Future. United Nations.

Welter, F. (2011). Contextualizing Entrepreneurship-Conceptual Challenges and Ways Forward. Entrepreneurship: Theory \& Practice, 35(1), 165-184. https://doi.org/10.1111/j.1540-6520.2010.00427.x

Wiklund, J., Davidsson, P., Audretsch, D. B., \& Karlsson, C. (2011). The Future of Entrepreneurship Research. Entrepreneurship: Theory \& Practice, 35(1), 1-9. https://doi.org/10.1111/j.1540-6520.2010.00420.x

Yüksel, I. (2012). Developing a Multi-Criteria Decision Making Model for PESTEL Analysis. International Journal of Business and Management, 7(24), 52-66. https://doi.org/10.5539/ijbm.v7n24p52

Zain, Zaharia, et al. (2006). Entrepreneurship Intention Among Malaysian Business Students. Canadian Social Science, 6(3), 34-44

Zaki, J. (July/August 2012). The curious perils of seeing the other side. Scientific American Mind. 20-21. https://doi.org/10.1038/scientificamericanmind0712-20

Zhang S. X., \& Cueto, J. (2015). The Study of Bias in Entrepreneurship. Entrepreneurship Theory and Practice, 41(3), 419-454. https://doi.org/10.1111/etap.12212

Zhao, H., Hills, G. E., \& Seibert, S. (2005). The mediating role of self-efficacy in the development of entrepreneurial attitudes. Journal of Applied Psychology, 90(6), 1265-1272. https://doi.org/10.1037/0021-9010.90.6.1265

\section{Copyright Disclaimer}

Copyright for this article is retained by the author(s), with first publication rights granted to the journal.

This is an open-access article distributed under the terms and conditions of the Creative Commons Attribution license (http://creativecommons.org/licenses/by/3.0/). 